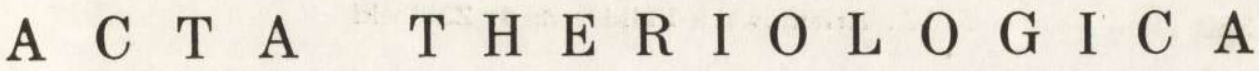

VOL. XVII, 29: $381-398$.

BIAEOWIEŻA

October, 1972

\author{
Anna ARŁAMOWSKA-PALIDER \& Jacek ZABŁOCKI
}

\section{Musculus Omotransversarius in the Light of Comparative Anatomy}

[With 5 Figs.]

\begin{abstract}
Studies made by the authors on representatives of Rodentia, Leporidae, Carnivora and Primates led them to conclude that both $\mathrm{m}$. omotransversarius and $m$. omotransversarius dorsalis are present in mammals with primarily formed superficial dorsal muscles. Among carnivores these two muscles are present in Mustelidae and beares, and among rodents in the squirrel, nutria and chinchilla. Musculus omotransversarius dorsalis is reduced in the dog, cat and raccoon, and also in representatives of Muridae and the guinea pig. This muscle is absent in the rabbit, while $m$. omotransversarius itself has undergone secondary splitting into two muscle units. The two muscles are generally present in Primates, $m$. omotransversarius dorsalis uniting with $m$. levator scapulae. In higher forms of the Hominoidea group $\mathrm{m}$. omotransversarius may undergo regression, although retaining $m$. omotransversarius dorsalis as the first dens of $m$. levator scapulae.
\end{abstract}

\section{INTRODUCTION}

Musculus omotransversarius is distinguished in domestic mammals included in NAV and occurs, according to data given in all veterinary anatomy textbooks, in the dog, cat, pig and in ruminants, being absent only in the horse. No muscle of this name is encountered in anthropotomy and therefore its homology with human muscles remains a debatable and confused question.

In anatomical literature on rodents: Greene (1955), Wood \& White (1950), Parson (1894), Dobson (1884), Mivart \& Murie (1866) m. omotransversarius is generally described under the name of $\mathrm{m}$. levator claviculae. In monographs dealing with the anatomy of the rabbit $\mathrm{Kra}$ u se (1884), and after him Gerhardt (1909), and contemporarily Terentev (1952), distinguish the so-called $m$. basiohumeralis and $m$. levator scapulae maior. C a n t i e r \& V e z in het (1968), like Popesko (1961), in describing the muscles of the rabbit under the name of $\mathrm{m}$. omotransversarius, only described what is termed by $\mathrm{Kr}$ a u se (1884) as $m$. levator scapulae maior, whereas $m$. basiohumeralis, as may be gathered from 
the description, is treated by them as a component part of $m$. cleidocephalicus (termed by them "la branche trapezienne«) which would appear to be completely erroneous. Olbrorth (1963) distinguishes $m$. omocleidotransversarius in the chinchilla and identifies it with Wood's \& White's (1950) m. levator claviculae. With regard to nutria $(\mathrm{K} \circ \mathrm{ch}, 1953)$ it can be presumed that what he terms $m$. omocleidomastoideus is $m$. omotransversarius in domestic mammals.

In literature on the Primates $m$. omotransversarius is described under various names: $M$. levator claviculae, $m$. atlanto-scapularis or omo-cervicalis. According to Hill (1953-1970) m. levator claviculae occurs generally in catarrhine and platyrrhine monkeys and runs from the atlas to the acromion. M i chaelis (1903) in describing muscles of the orangutan, chimpanzee and baboon distinguishes $m$. omo-cervicalis in these animals, which in the case of the chimpanzee begins on proc. mastoideus and in the orang-utan on the atlas, and ends on the acromial end of the clavicle, while in the baboon it runs from the atlas to proc. acromialis. According to $\mathrm{Huxley}$ (cited after $\mathrm{Mich}$ aelis, 1903) a muscle behaving in a similar way may sometimes occur as a variant in man also. It may be added here that one of the more frequent variants of $m$. trapezius, mentioned in anthropotomical text-books (M arciniak, 1964; Bochenek, 1953; R a uber$\mathrm{Kopsch}, 1954$ ), consisting in the presence of an additional bundle running from the atlas to the acromial part of the clavicle, suggests its homology with $m$. omotransversarius in lower mammals. Data on occurrence of the dorsal part of this muscle in higher Primates are not clear. In Žedenov's opinion (1962) a characteristic muscle in Primates is $m$. atlanto-scapularis ventralis, from which a small muscle bundle running to the clavicle as $m$. levator claviculae may separate. In addition to the above-mentioned muscles $m$. atlanto-scapularis dorsalis s.m. levato* scapulae dorsalis s.m. omo-cervicalis dorsalis, running from the atlas to the dorsal angle of the scapula, may also occur.

As shown by the review of relevant literature the data on the occurrence in Rodentia, Leporidae and Primates of a muscle homologous with $m$. omotransversarius in domestic animals are not clear. The great variety of terms used by different authors and the frequent lack of exact descriptions present very real obstacles to the use of literature on this subject, in fact it is even difficult exactly to describe this muscle in representatives of the mammals mentioned. It can only be said that it is accurately described in domestic animals, but its homology with muscles of rodents or Primates is still an open question. The genesis of this muscle continues to form a subject for debate. Some authors consider that it connects with the muscles of nerve XI as $m$. sternocleidomastoideus (P e r l, 1903) and $m$. trapezius (Gurlt cited after B a u m, 1936), and others as $m$. serratus ventralis ( $\mathrm{L} \mathrm{e} \mathrm{ch}$ e, 1900) and $m$. rhomboideus ( $\mathrm{R} \mathrm{i} \mathrm{bbing,} \mathrm{1938).}$

The purpose of the present study is to establish which of the muscles occurring in the more important representatives of Rodentia, Leporidae, Carnivora and Primates is a homologue of $m$. omotransversarius in domestic mammals, and at the same time to present the process of its phylogenesis in the groups of mammals mentioned. 
The difference of this muscle in different species, its primary or secondary connection with the foregoing muscles made it necessary to take these muscles also into consideration, of course only to the degree necessary for elucidation of the main problem.

Observations were made on bodies of the following species of animals: Tupaia glis - 3, Galago senegalensis - 4, Lori tardigradus - 1, Arctocebus calabarensis - 1, Saimiri sciureus - 1, Cebus apella - 2, Aotus trivirgatus - 3, Colobus badius - 2, Papio cynocephalus - 4, Macaca mulatta - 4, Hylobates lar - 1, Symphalangus syndactylus - 2 Primates, Cavia porcella - 10, Myocastor coypus - 8, Sciurus vulgaris - 4, Chinchilla laniger - 1, Rattus norvegicus - 20, Mus musculus - 20, Mesocricetus auratus - 20, Cricetus cricetus - 2, Dolichotis patagonica - 1 - Rodentia, Oryctolagus cuniculus - 20 - Lagomorpha, Canis familiaris - 20, Felis catus - 20. Selenarctos thibetanus - 3, Martes martes, Martes foina - 5, Mustela lutreola - 9, Mustela putorius furo - 10, Mustela putorius - 7, Mustela nivalis - 2, Procyon lator - 2-Carnivora.

\section{RESULTS}

\section{Carnivora}

Musculus omotransversarius in the dog begins on the alae and dorsad arch of the atlas, and in the cat also at the base of the occiput, and runs in the direction of the scapula, ending on its acromion. Part of the muscle bundles furthest dorsad disappear in the fascia of the scapular region. The fact merits mention that the dorsal margin of this muscle near the terminal insertion on the scapula fuses with the cervical part of $m$. trapezius (Fig. 1).

The behaviour of the neighbouring muscles is as follows: $m$. trapezius has pars thoracica and pars cervicalis, the latter being relatively weakly developed and beginning only on the septum nuchae. $M$. rhomboideus has three parts, of which pars thoracica and pars cervicalis correspond to $m$. rhomboideus minor and $m$. rhomboideus maior in man, while pars capitis, which does not occur in man, runs to the occiput. The counterpart of $m$. sternocleidomastoideus in man is $m$. sternocephalicus and $m$. cleidocephalicus. The latter divides distinctly into $m$. cleidomastoideus, beginning on the mastoid, and $m$. cleidocervicalis, beginning on os occipitale and septum nuchae. The latter is sometimes described in the cat under the name of $\mathrm{m}$. clavotrapezius ( $\mathrm{T}$ a ylor \& Weber, 1951). Pars cervicalis $m$. serratus ventralis, corresponding to $m$. levator scapulae in Primates, begins on the transverse processes of the cervical 
vertebrae, but starts from the third vertebra and forms a whole with pars thoracica of $m$. serratus corresponding to $m$. serratus anterior in man. It is remarkable that in the dog and cat $m$. omotransversarius is more closely connected morphologically only with pars cervicalis of $m$. trapezius, with which it fuses near proc. acromialis scapulae.

In the raccoon the above mentioned muscles behave similarly to those in the dog and cat, the only difference here being the far stronger development of pars capitis of $m$. rhomboideus.

Topographical relations in Mustelidae and bears (Fig. 2a), however, differ from the above. In these animals both $m$. omotransversarius and all the other muscles mentioned above occur, and in addition to them

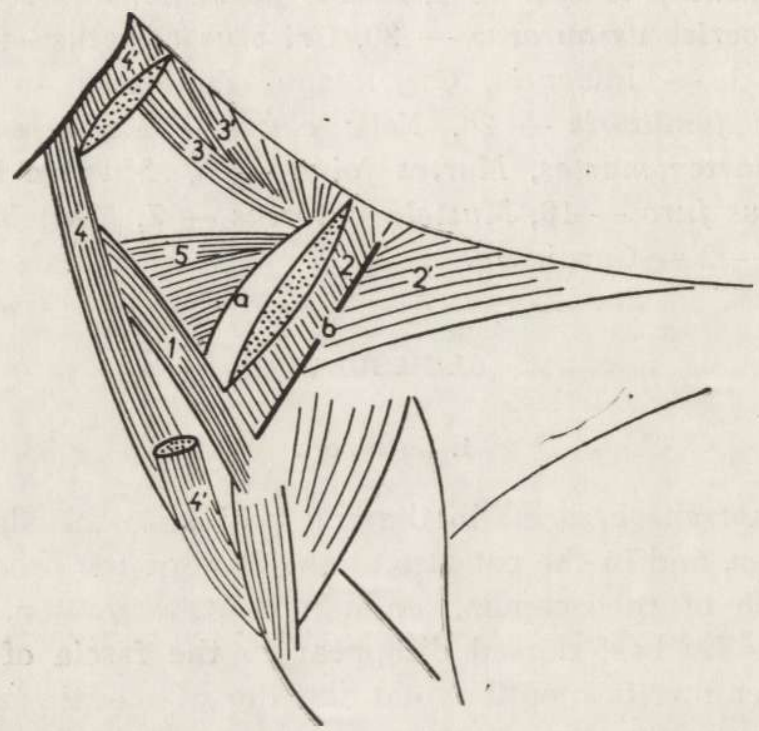

Fig. 1. Diagram of muscles in superficial layer of neck in Canidae and Felidie. 1. m. omotransversarius, 2 and $2^{\prime}-$ pars cervicalis and pars thoracica of $m$. trapezius, 3 and $3^{\prime}-$ pars capitis and pars cervicalis of $m$. rhomboideus, $4-m$. cleidomastoideus, $4^{\prime}-m$. cleidocervicalis, 5 - pars cervicalis of $m$. serratus ventralis, a - scapula.

there is a further muscle belly not distinguished in veterinary anatomy. This muscle begins jointly with $m$. omotransversarius on the atlas, then the two muscles separate in the form of the arms of a letter V, m. omotransversarius running to proc. acromialis scapulae, while the additional muscle belly runs to the capitad angle of the scapula, ending at the base of the crest. At its scapular insertion this muscles fuses with pors capitis $m$. rhomboideus. In view of the fact that the term $m$. omotrarsversarius is confirmed as correct in NAV this muscle belly fully merts the term $m$. omotransversarius dorsalis. Its definition as pars dorsalis $m$. omotransversarius may lead to misunderstandings, as $m$. omotrars- 
versarius itself may undergo secondary division into a ventral and dorsal part. It may also be mentioned that $m$. omotransversarius does not fuse in these animals with $m$. trapezius, but owing to the presence of
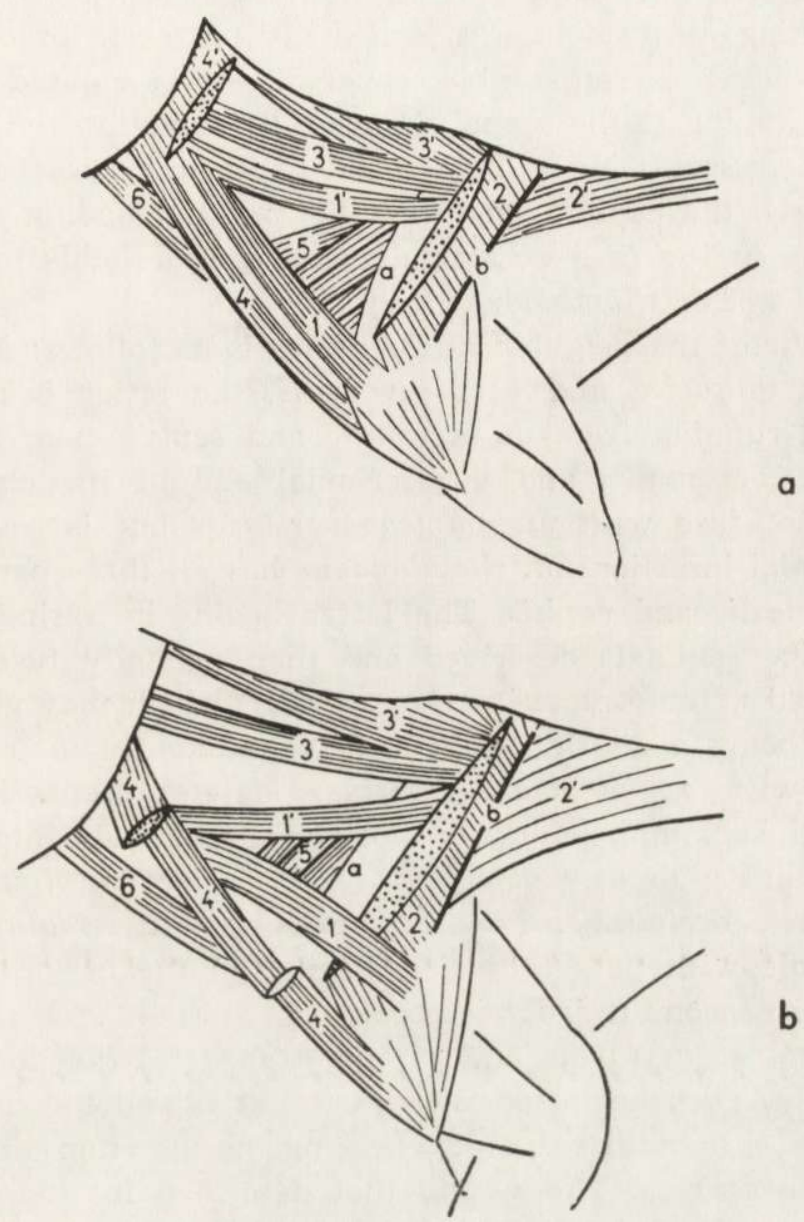

Fig. 2. Diagram of muscles in superficial layer of neck in a: Mustelidae, bears, squirrels and tupaia, b - nutria and chinchillas.

1 - $m$. omotransversarius, $1^{\prime}-m$. omotransversarius dorsalis, 2 and $2^{\prime}-$ pars cervicalis and pars thoracica of $m$. trapezius, 3 and $3^{\prime}-$ pars capitis and pars cervicalis of $m$. rhomboideus, 4 and $4^{\prime}-m$. cleidocephalicus, 5 - pars cervicalis of $m$. serratus ventralis, $6-m$. sternocephalicus, a - scapula.

$m$. omotransversarius dorsalis is clearly connected with $m$. rhomboideus. The behaviour of the other neighbouring muscles is similar to that found in the dog, cat and raccoon. 


\section{Rodentia and Leporidae}

Among rodents we found both $m$. omotransversarius and $m$. omotransversarius dorsalis present in the nutria, chinchilla and squirrel. In the nutria the two muscles begin at the basis of os occipitale, then separate. Running ventrad the muscle belly passes to proc. acromialis scapulae and, which is remarkable, covers he most capitad bundles of $m$. trapezius, running to the scapula. This belly undoubtedly corresponds to $m$. omotransversarius NAV. The second belly (not described in literature) runs above the capitad angle of the scapula, ending at the base of its crest. As in the case of Mustelidae and bears, this muscle fuses with pars capitis of $m$. rhomboideus (Fig. 2b).

The behaviour of the neighbouring muscles is as follows: M. trapezius possesses pars thoracica and pars cervicalis, the latter being strongly developed and running from os occipitale and septum nuchae to crista scapulae, proc. acromialis and the acromial end of the clavicle. This muscle does not fuse with $m$. omotransversarius but is covered by it near the acromial insertion. M. rhomboideus has all three parts, i.e. pars thoracica, cervicalis and capitis. The latter begins in a similar way to that in the other animals described and then partially fuses with the above-mentioned $m$. omotransversarius dorsalis (which may give a visual impression of being a division of it) and consequently $m$. rhomboideus also connects with $m$. omotransversarius. $M$. sternocephalicus divides into two bellies beginning jointly on the clavicle, namely into $\mathrm{m}$. cleidomastoideus, running to os mastoideum and $m$. cleidooccipitalis ending on squama ossis occipitalis. Pars cervicalis of $m$. serratus ventralis, forming a whole with pars thoracica, begins on the cervical vertebrae starting from the second (third) vertebra.

Both $m$. omotransversarius and $m$. omotransversarius dorsalis occur in the chinchilla. They begin together on the atlas and the first of them extends to proc. acromialis scapulae, covering the insertion of the capitad bundles of $m$. trapezius. The second (not described in literature) fuses with pars capitis of $m$. rhomboideus and ends at the base of crista scapulae (Fig. 2b). Mm. rhomboideus and trapezius behave similarly to similarly to those in nutria. Both Wood \& White (1950) and O l brorth (1963) distinguish yet a third part in this muscle, that is, clavotrapezius or m. trapezius clavicularis. It is, however, m. cleidooccipitalis which together with $m$. cleidomastoideus begins on the clavicle and runs to os occipitale, which these authors describe under this name. In rodents, irrespective of the presence of this muscle, pars cervicalis of $m$. trapezius has an insertion on both os occipitale and the clavicle.

Both $m$. omotransversarius and omotransversarius dorsalis occur in 
the squirrel. These muscles begin on the atlas and end in the same way as in the chinchilla, the only difference being that in the squirrel pars cervicalis of $m$. trapezius does not extend to the clavicle and its lower edge runs parallel to $m$. omotransversarius and consequently is not covered by it (Fig. 2a). The behaviour of the other muscles is similar to that described for the above-mentioned rodents.

In representatives of Rodents of the Muroidea group, that is the rat, mouse and hamster, only $m$. omotransversarius is present. This muscle begins on the atlas and runs to proc. acromialis scapulae, covering the capitad bundles of pars cervicalis $m$. trapezius at its acromial insertion (Fig. 3). M. trapezius has a strongly developed pars cervicalis which begins on occipitale and septum nuchae and ends on proc. acromialis, crista scapulae and the acromial end of the clavicle. $M$. rhomboideus has three typical parts. Pars capitis is a completely separated muscle

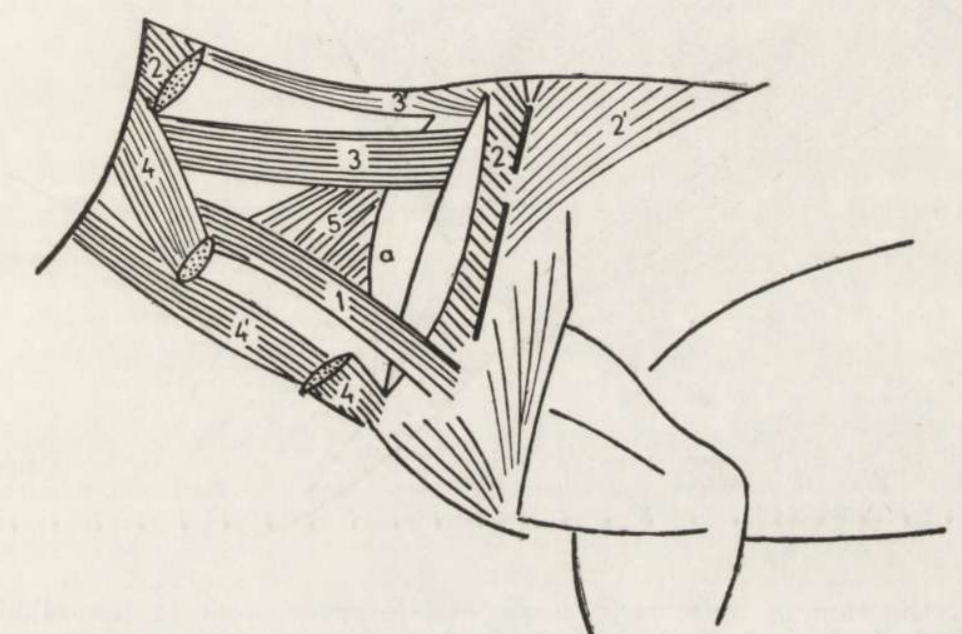

Fig. 3. Diagram of muscles in the superficial layer of neck in Muridae. 1 - m. omotransversarius, 2 and $2^{\prime}-$ pars cervicalis and pars thoracica of $m$. trapezius, 3 and $3^{\prime}-$ pars capitis and pars cervicalis of m. rhomboideus, 4 and $4^{\prime}-m$. cleidocephalicus, 5 - pars cervicalis of $m$. serratus ventralis, a - scapula.

which runs from squama ossis occipitalis to the upper part of crista scapulae. M. cleidocephalicus is represented by two well-separated units, $m$. cleidomastoideus, ending on os mastoide and $m$. cleidooccipitalis (described as $m$. clavotrapezius) running to squama ossis occipitalis. Pars cervicalis of $m$. serratus ventralis, like that in other rodents, begins on the second (in the hamster the third) cervical vertebra.

In the guinea pig also only $m$. omotransversarius occurs which, however, as distinct from the foregoing rodents, begins at the base of os occipitale, and ends in a typical way on proc. acromialis. M. trapezius consists of pars thoracica and pars cervicalis, the latter extending from 
os occipitale and septum nuchae to proc. acromialis and crista scapulae. $M$. rhomboideus has three typical parts which, as distinct from the animals described above, forms one compact whole. Pars capitis of this muscle, strongly developed, begins on squama ossis occipitalis and ends at the base of the crest and upper angle of the scapula. Pars cervicalis of $m$. serratus ventralis begins in the same way as in the hamster, but forms a separate unit not connecting with pars thoracica of this muscle. A single $m$. cleidocephalicus extends from the clavicle to os occipitale and the mastoid.

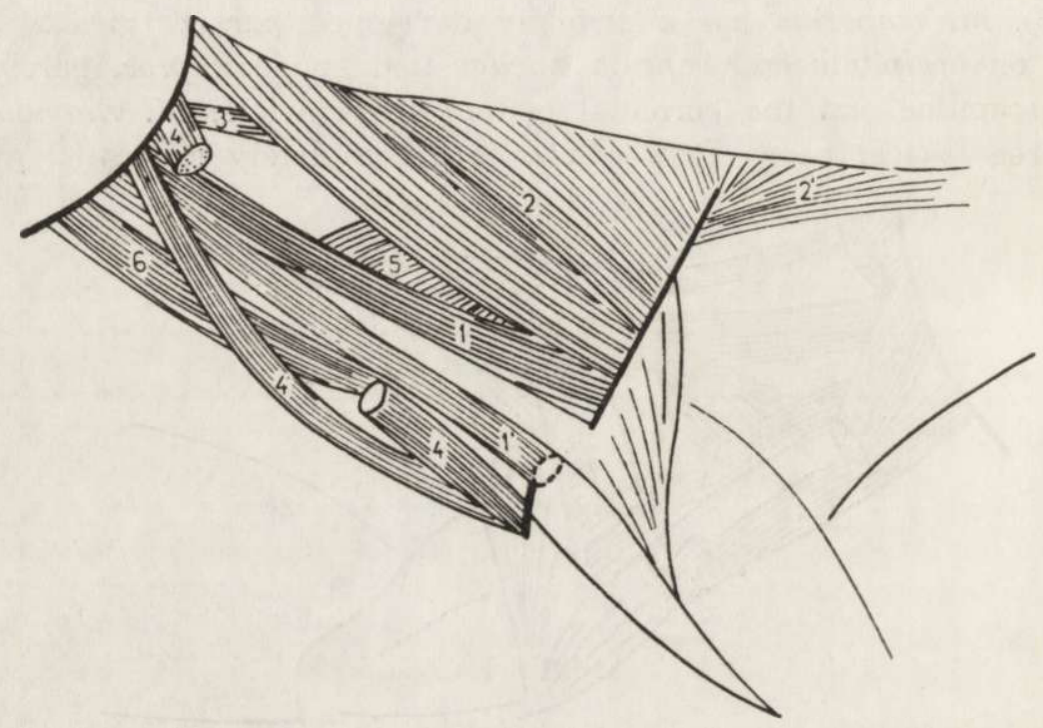

Fig. 4. Diagram of muscles in superficial layer on neck in the rabbit. 1 - pars dorsalis of $m$. omotransversarius, $1^{\prime}$ - pars ventralis of $m$. omotransversarius, 2 and $2^{\prime}$ - pars capitis and pars cervicalis of $m$. trapezius, 3 - pars capitis of $m$. rhomboideus, $4-m$. cleidocephalicus, $4^{\prime}-m$. sternocephalicus, $5-$ pars cervicalis of $m$. serratus ventralis, $6-m$. sternofacialis.

In the Patagonian hare (Dolichotis patagonica) also $m$. omotransversarius dorsalis is absent and only $m$. omotransversarius, which undergoes some modifications, is retained. Beginning on the base of os occipitale it fuses in the region of the scapula with the lower edge of $m$. trapezius and together with part of its fibres runs to the fascia of the arm, covering the shoulder joint. Behaviour of the neighbouring muscles is similar to that observed in nutria.

In the rabbit, the only representative of Leporidae we examined, the homologue of $m$. omotransversarius NAV is probably formed by two muscles. They begin jointly on the base of os occipitale, then divide 
into two branches, of which one extends to proc. acromialis scapulae (its caudal part termed paracromion) and the second to the rudimentary clavicle fusing with the well developed pars clavicularis of $m$. deltoideus (Fig. 4). The first of these muscles is described in literature as m. levator scapulae magnus or $m$. omotransversarius, the second as $m$. basiohumeralis. It would appear that in the rabbit $m$. omotransversarius, as the result of the characteristic development of proc. acromialis scapulae and the partial regression of the clavicle, divided into two bellies, one of which entered into close contact with pars clavicularis of $m$. deltoideus. $M$. trapezius begins in a way typical of the majority of rodents and runs to proc. acromialis and crista scapulae. M. rhomboideus consists of pars thoracica and pars cervicalis forming one whole. Pars cervicalis of $m$. serratus ventralis reaches only as far as the third cervical vertebra, as in the case of the guinea pig. M. sternocleidomastoideus consists of a single $m$. cleidocephalicus and sternocephalicus.

In addition to the above mentioned muscles in the rabbit there is an additional muscle, termed $m$. levator anguli scapulae ( $\mathrm{K} \mathrm{r}$ a u s e, 1884, et al.) or m. levator scapulae (Cantie r \& Vezinhet, 1968). This muscle runs from squama ossis occipitalis to the caudad angle of the scapula and most probably forms a weakly developed but separate pars capitis of $m$. rhomboideus.

\section{Primates}

In the majority of cases both $m$. omotransversarius and $m$. omotransversarius dorsalis are present in Primates. Cases in which one of them is absent are encountered only in representatives of Pongidae and in some Lemuroidea (Prosimiae).

In Tupaia glis, the most primitive representative of the last group, the two muscles are present, beginning on the atlas and behaving in a similar way to that in primitive rodents, e.g. squirrels. M. omotransversarius runs to proc. acromialis scapulae, does not cover $m$. trapezius but is situated parallel to it (Fig. 2a). M. omotransversarius dorsalis, on the other hand, fuses with pars capitis of $m$. rhomboideus and ends at the base of crista scapulae. As in the case of rodents, it gives the visual impression of an additional part of $m$. rhomboideus. M. trapezius does not reach the clavicle but ends on proc. acromialis. M. cleidocephalicus has two typical parts: $m$. cleidomastoideus and $m$. cleidooccipitalis. M. rhomboideus has all three parts, and $m$. levator scapulae does not begin until the second cervical vertebra and forms one whole with $m$. serratus anterior (pars thoracica of the $m$. serratus ventralis). In othe representatives of Lemuroidea, such as Galago senegalensis, 
Lori tardigradus and the Anguantibo, m. omotransversarius is present, and runs from the atlas to proc. acromialis scapulae, covering $m$. trapezius with its acral insertion. In the galago there is most certainly no $m$. omotransversarius dorsalis, and $m$. levator scapulae, as in other lower mammals, does not reach the atlas. The same applies to the lori, but there is some doubt as to the existence of $m$. omotransversarius dorsalis in the anguantibo, in which $m$. levator scapulae, as distinct from that in the previously mentioned representatives of Lemuroidea, reaches the atlas. This might suggest that the first dens of this muscle (as in the case of monkeys) is here the homologue of $m$. omotransversarius dorsalis. While, however, in monkeys the first dens of $m$. levator scapulae is undoubtedly the connected $\mathrm{m}$. omotransversarius dorsalis, in the case of the anguantibo this cannot be stated with complete certainty as it is completely anastomosed with the other dentes of $m$. levator scapulae and ends together with them only on the costal surface of the scapula. $M$. rhomboideus is modified in the lori and anguantibo, unlike the tupaia, and in the former does not possess pars capitis typical of the tupaia and lower mammals, this part being present in extremely rudimentary form in the galago only. $M$. trapezius in the galago, lori and anguantibo runs to the clavicle and is covered by $m$. omotransversarius.

In the representatives of the Ceboidea and also Cercopithecoidea groups both $m$. omotransversarius and $m$. omotransversarius dorsalis are present (Fig. 5), the first of them beginning on the atlas and running to proc. acromialis scapulae and, as must be emphasised, is covered by $m$. trapezius. In the Aotus trivirgatus (Ceboidea) this muscle also runs to proc. acromialis with the difference, however, that it covers the capitad fascia of $m$. rhomboideus, as in the case of the majority of rodents. The counterpart of $\mathrm{m}$. omotransversarius dorsalis in lower mammals is here undoubtedly the first dens of $m$. levator scapulae. This muscle begins together with $m$. omotransversarius on the atlas and runs to the upper angle of the scapula. It must be recalled here that in rodents, carnivores and the tupaia $m$. levator scapulae did not begin until the second or third cervical vertebra. Therefore in monkeys the first dens of $m$. levator scapulae running from the atlas most probably constitutes $m$. omotransversarius dorsalis, as is also shown by its joint start with $m$. omotransversarius. As a result of the weak development of $m$. rhomboideus it has here lost its original connection with it.

Among representatives of the group Hylobatinae, both muscles were found to be present in Hylobates lar. $M$. omotransversarius began in this case on the atlas and ended on the acromial end of the clavicle (on the site of articulatio acromioclavicularis) under the strongly developed $m$. trapezius. $M$. omotransversarius dorsalis begins together with it and 
here forms the first dens of $m$. levator scapulae. In the gibbon $m$. rhomboideus has no pars capitis at all, and $m$. levator scapulae completely loses connection with $m$. serratus anterior and consists of four dentes running from the first four upper cervical vertebrae to the upper angle of the scapula. The first dens of this muscle is undoubtedly the homologue of $m$. omotransversarius dorsalis in lower mammals. The following details bear out the correctness of this opinion: this dens begins jointly with $m$. omotransversarius and ends slightly differently from the other dentes on the upper angle of the scapula from the lateral side.

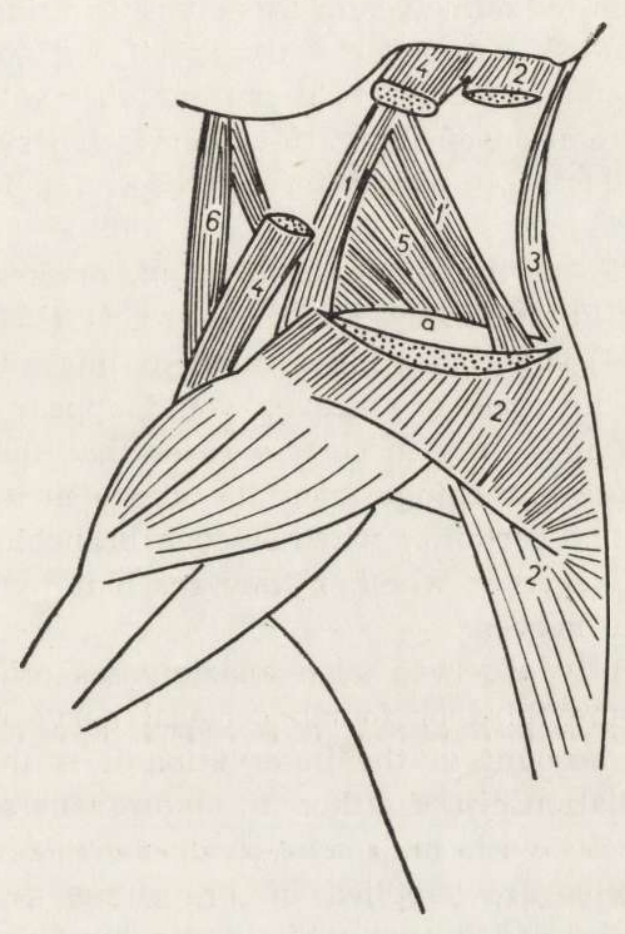

Fig. 5. Diagram of muscles in superficial layer of neck in Primates. $1-m$. omotransversarius, $1^{\prime}-m$. omotransversarius dorsalis, 2 and $2^{\prime}-$ pars capitis and pars cervicalis of $m$. trapezius, $3-m$. rhomboideus, $4-m$. cleidocephalicus, $5-m$. levator scapulae, $6-m$. sternocephalicus, a - scapula.

In the Symphalangus syndactylus examined there was no $m$. omotransversarius, but $m$. omotransversarius dorsalis was present, of course in such cases joined to an even greater degree with $m$. levator scapulae and giving the impression of being its first and strongest dens.

In conclusion reference must be made to the question of the innervation of the two $\mathrm{mm}$. omotransversarii dorsales, which, although taken into consideration during observations, has not been dealt with so far, 
since in our particular studies application of the most frequently used criterion of the homology of muscles on the basis of innervation does not provide a definite and unequivocal answer. It can be stated on the basis of the observations we made that $m$. omotransversarius, and also $m$. omotransversarius dorsalis, are innervated exclusively (or almost exclusively) by the cervical nerves, that is, by the same elements which serve $m$. rhomboideus and pars cervicalis of $m$. serratus ventralis.

In view of the fact that data in literature on homology of nomenclature of the nerve branches innervating these muscles are very contradictory, we have limited ourselves in this study to using only the general term "cervical nerves « without exactly specifying them. It would be beyond the scope of our studies to carry out observations providing an unequivocal interpretation of the various cervical nerves in the animals examined, and in fact this would form a basis for further studies on this question.

The studies made on the innervation of $m$. omotransversarius show that data contained in studies by E $1 \mathrm{l}$ e $\mathrm{n}$ be r g e r (1943), B a u m (1936) and Nickel (1954) suggesting innervation of this muscles in domestic animals solely by the accessory nerve, would appear to be completely erroneous. At most it is only in certain cases that this nerve might be reached by very fine branchings from the above mentioned nerve, and in addition there is no certainty whether such branchings originate from the nucleus of the nerve or whether they reach it by means of anastomoses with cervical nerves.

We not infrequently observed such anastomoses originating from the ventral branch of the third or fourth cervical nerve during the course of our studies. On account of the innervation it is therefore necessary to rule out close relationship of either $m$. omotransversarius, or $m$. omotransversarius dorsalis with $m$. sterno-cleido-mastoideus and $m$. trapezius, as these muscles are supplied by branchings from the accessory nerve. It can only be added that while some bundles of $m$. omotransversarius receive nerve fibres from the accessory nerve, this fact can only provide evidence that during onto- and phylogenesis this muscle assimilated a small number of myomeres from the nucleus of muscles of the terminal branchiate arches. Also we are unable to give a definite interpretation, on the basis of innervation only, as to the closer relationship of the muscles examined with $m$. rhomboideus or $m$. serratus ventralis, since the latter two muscles are also innervated by branchings of the cervical nerves. It is only the topography of the muscle bellies referred to (in this case of course the chief criterion of homology) and the behaviour of their insertions, and also consideration of the presence of numerous transitional forms between the two extreme forms of these 
muscles in different species which can provide evidence, in our opinion, of the correctness of R i b bing's view (1938) on the genetic connection of $m$. omotransversarius with $m$. rhomboideus.

\section{DISCUSSION}

The studies made of $m$. omotransversarius show that it occurs commonly in Carnivora, Rodentia, the rabbit and the majority of Primates. In mammals characterized by more primitive formation of the musculature of this region $m$. omotransversarius is accompanied by an additional belly defined by us as $m$. omotransversarius dorsalis.

M. omotransversarius is considered by different authors as a splitting of $m$. trapezius or $m$. sternocleidomastoideus which, however, in the light of our studies, must be considered as erroneous. This muscle exhibits closer genetic connection with $m$. rhomboideus, which is evident in the more primitive mammals possessing $m$. omotransversarius dorsalis connecting $m$. omotransversarius with $m$. rhomboideus. It would appear necessary to emphasise here that it is difficult in any case to consider $m$. omotransversarius as the product of the splitting of one of such muscles, since they only made their appearance in this form in mammals and, what is more important, simultaneously with $\mathrm{m}$. omotransversarius.

It is therefore possible to speak only of genetic connection with one of the above-mentioned muscles (this connection in fact applies to earlier stages of development) and the most probable would appear to be connection with $\mathrm{m}$. rhomboideus. Both $\mathrm{mm}$. omotransversarii occur in primitive carnivores, rodents and Primates, and also marsupials, and consequently must by now have reached the stage of their common ancestors, at least the stage of Panthotheria. At the same time it would appear very likely that it was at this stage that $m$. rhomboideus possessed three parts: pars thoracica, pars cervicalis and the strongly developed pars capitis. M. serratus ventralis (pars cervicalis) did not reach the first cervical vertebra and formed one whole with pars thoracica of this muscle. M. cleidocephalicus had two parts: $m$. cleidooccipitalis and $m$. cleidomastoideus. All these characters (together with the presence of both $\mathrm{mm}$. omotransversarii) occur in primitive rodents, carnivores and Primates. Deviations from the above pattern are of an undoubtedly secondary character and one of them is reduction of $m$. omotransversarius dorsalis.

In the rabbit, in our opinion, the originally single-form $\mathrm{m}$. omotransversarius underwent secondary division into two separate muscle, while $m$. omotransversarius dorsalis underwent regresion. This point of view 
is at variance with that of $\mathrm{Leche}$ (l.c.), according to whom the so-called $m$. levator scapulae maior forms the dorsal part of $m$. omocleidotransversarius (which would correspond to our $m$. omotransversarius dorsalis) and $m$. basiohumeralis is the ventral part of this muscle (which would correspond to $m$. omotransversarius). This view must, however, be considered erroneous, as the terminal insertion of the so-called $m$. levator scapulae maior completely coincides with te insertion of the typical $m$. omotransversarius and not with $m$. omotransversarius dorsalis. Consequently $m$. basiohumeralis, situated more ventrad, should be considered as the secondary split of the originally united $m$. omotransversarius, which may be the result of specific modification of the shape of proc. acromialis. In summing up the foregoing the conclusion must be reached that in the rabbit it is permissible, and even essential, to speak of pars dorsalis and pars ventralis of $m$. omotransversarius and of the reduction of $m$. omotransversarius dorsalis. Although the specific muscle running from squama ossis occipitalis to the caudad angle of the scapula, which can be suspected of homology with $m$. omotransversarius dorsalis, still occurs in this animal, it is more probable that it constitutes a specifically modified and separate (as in some rodents), pars capitis of $m$. rhomboideus. It would also appear that it is impossible in the case of the rabbit to speak of the fully formed $m$. brachiocephalicus as is the case in ungulates and carnivores, since in the rabbit the clavicle is still relatively well preserved and although it has lost direct connection with the scapula and sternum, it is nevertheless relatively large and connected with them by ligaments. Pars clavicularis of $m$. deltoideus here connects more closely with $m$. basiohumeralis, or (in our opinion) pars ventralis of $m$. omotransversarius, while $m$. cleidocephalicus has an insertion on the retained osseous part of the clavicle. If, however, this whole muscle complex is treated as the nucleus of $m$. brachiocephalicus, then it should be emphasised that it is composed of: pars clavicularis of $m$. deltoideus, $m$. cleidocephalicus and pars ventralis of $m$. omotransversarius.

Discussion of the behaviour in Primates of the muscles in question merits particular attention. In the most primitive representative of this group (tupaia) there are two $\mathrm{mm}$. omotransversarii. In some Lemuroidae there is no $m$. omotransversarius dorsalis, while $m$. omotransversarius is retained. In all of the monkeys examined from the Ceboidea and Cercopithecoidea groups these two muscles are present, as they are in primitive mammals. A certain modification, however, occurs here consisting in $m$. omotransversarius dorsalis, which begins jointly with $m$. omotransversarius, separating in its terminal insertion from $m$. rhomboideus and consequently giving the impression of the first dens of $m$. levator scapulae. In anthropoid apes such as, for instance, in the gibbon 
examined, $m$. omotransversarius and $m$. omotransversarius dorsalis may occur, the latter being united to an even greater degree in $m$. levator scapulae, since pars capitis $m$. rhomboideus is completely absent in the gibbon. The first dens running together with $m$. omotransversarius from the atlas ends on the upper angle of the scapula (from the lateral side). The foregoing shows that this dens, only slightly transformed and attached to levator scapulae, constitutes $m$. omotransversarius dorsalis. In certain cases, among representatives of Hylabatinae, there is no $\mathrm{m}$. omotransversarius, as in the case of the Symphalangus syndactylus examined, but $m$. omotransversarius dorsalis is always present here, of course united to an even greater degree with $m$. levator scapulae.

Generally speaking it may be said that tendencies to reduction of $m$. omotransversarius can be traced in many representatives of Pongidae, since as can be gathered from descriptions in literature (Ž e de nov, $1962)$, this muscle exhibits considerable individual variation. This tendency has become a typical phenomenon in man and $m$. omotransversarius appears here only as a variant $(\mathrm{H} \mathrm{uxley}$ cited after $\mathrm{Mich}$ a elis 1903). It must be mentioned that a process of this kind, consisting in reduction of $m$. omotransversarius while retaining $m$. omotransversarius dorsalis, is a phenomenon which is at least rare in mamals. The reverse process is far more frequently found, i.e. reduction of $m$. omotransversarius dorsalis while retaining $m$. omotransversarius.

When the results of our studies are compared with data in literature on other domestic mammals, that is, domestic ungulates, the conclusion may be reached that in ruminants $m$. omotransversarius dorsalis has undergone regression, while $m$. omotransversarius is retained. Descriptions of these muscles in pigs give rise to doubt, since the data given by Ellenberger (1943) and Nickel (1954) for this animal show that pars cervicalis $m$. serratus ventralis begins from the first cervical vertebra and ends not only on the serrated surface of the scapula, but also on its capitad angle from the lateral side. Such descriptions suggest that in pigs the first dens of this muscle, running from the atlas, may in fact constitute $m$. omotransversarius dorsalis. In addition data in literature show that $m$. omotransversarius is present in pigs.

In conclusion yet another detail, connected with the phylogenesis of another muscle, namely $m$. trapezius, should be taken into consideration. As already mentioned $m$. omotransversarius may occupy three different positions in relation to the latter muscle. It may thus be situated parallel to the lower edge of $m$. trapezius, may cover its capitad bundles, or conversely may be covered by it in its terminal part. When considering which of the three above-mentioned kinds of behaviour of m. omotransversarius in relation to $m$. trapezius is the original one, it is not difficult 
to reach the conclusion that only the first possibility can be considered, as the last two cancel each other out. It would follow from this that originally $m$. trapezius did not reach the clavicle in mammals, since the parallel situation of the two muscles is possible only in this particular case. Confirmation of the correctness of this opinion can be provided by the fact that in the squirrel or tupaia, which possess a well developed clavicle, $m$. trapezius does not reach it. Extension of the insertion of $m$. trapezius to the clavicle, encountered in many rodents, marsupials and Primates, is probably of a secondary character. In such cases the bundles of $m$. trapezius, in acquiring new field for insertion, extend to the clavicle under or over the previously existing $m$. omotransversarius which reaches proc. accromialis.

\section{REFERENCES}

1. Baum W. \& Zietschmann O., 1936: Anatomie des Hundes. P. Parey, 1: 108-150. Berlin.

2. Bochenek A., 1953: Anatomia człowieka. Państw. Zakł. Wyd. Lek., 2: 1-339. Warszawa.

3. Cantier J. \& Vezinhet A., 1968: Guide pour la dissection et l'identification des principaux muscles de la carcasse chez le lapin. Ann. Biol. Anim., Biophys., 8: 107-139. Paris.

4. Dobson G., 1884: On the myology and visceral anatomy of Capromys melanurus with a description of the species. Proc. zool. Soc. Lond.: 233-250.

5. Ellenberger H. \& Baum W., 1943: Handbuch der vergleichenden Anatomie der Haustiere. Springer: 194-330. Berlin.

6. Gerh a rdt U., 1909: Das Kaninchen. W. Klinkhardt: 129-174. Leipzig.

7. Greene E., 1955: Anatomy of the rat. Hafner: 39-56. New York.

8. Hill W., 1953-1970: Primates, Comparative anatomy and taxonomy. The Univ. Press, 1-8: 1-798. Edinburgh.

9. Koch T., 1953: Beiträge zur Anatomie des Sumpfbibers (Myopatamus s. Myocastor coypus). S. Hirzel: 59-75. Leipzig.

10. Krause W., 1884: Die Anatomie des Kaninchen. W. Engelman: 136-168. Leipzig.

11. Le che W., 1874-1900: Muskulatur [In Bronn: "Klassen und Ordnungen des Tier-Reichs"] C. Winter'sche Verlagshandl. 1: 649-919. Leipzig.

12. Marciniak T., 1964: Anatomia prawidłowa człowieka. Państw. Zakł. Wyd. Lek., 1: . Warszawa.

13. Michaelis P., 1903: Beiträge zur vergleichenden Myologie des Cynocephalus babuin, Simia satyrus, Tryglodytes niger. Arch. f. (Anat. u.) Physiol.: 209223. Leipzig.

14. Mivart St. \& Murie J., 1866: On the anatomy of the Crestad Agonti ( $\mathrm{Da}$ syprocta cristata). Proc. zool. Soc. Lond.: 383-417.

15. Nickel R., Schummer A. \& Seiferle E., 1954: Lehrbuch der Anatomie der Haustiere. P. Parey, 1: 221-460. Berlin.

16. Nomina anatomica veterinaria, 1968: Intern. Com. Vet. Anat. Nomenclature: 1-146. Vienna. 
17. Olbrorth H., 1963: Zur Anatomie des Bewegungsapparates der Chinchilla (postkraniale Bereich). Inaug. Diss.: 1-76. München.

18. Pars on F., 1894: On the myology of the Sciuromorphine and Hystricomorphi. ne Rodents. Proc. zool. Soc. Lond.: 251-296.

19. Perl H., 1903: Über den $M$. omotransversiarius. Schwalbes Jahresbericht: 266-270. Berlin.

20. Popesko P., 1961: Atlas anatomii topograficznej zwierząt gospodarskich. Państw. Wyd. Rol. Leśn., 1: 1-215. Warszawa.

21. Rauber-Kopsch, 1954: Lehrbuch und Atlas der Anatomie des Menschen. G. Thieme, 1: 440-618. Leipzig.

22. Ribbing L., 1938: Die Muskeln und Nerven der Extremitäten. [In: Bolk L. „Handbuch der vergleichenden Anatomie der Wirbeltiere«]. Urban u. Schwarzenberg, 5: 543-656. Berlin.

23. T a y lor W. \& W e ber R., 1951: Functional mammalian anatomy (with special reference to the cat). L. van Nostrand: $87-154$. New York.

24. Terentev P. \& Dubinin V., 1952: Krolik. Sovetska Nauka: 175-206. Moskva.

25. Wood A. \& White R., 1950: The myology of the Chinchilla. J. Morphol., 86: $547-597$.

26. Žedenov W., 1962: Sravnitelnaja anatomija primatov. Izd. Vysšaja Škola: 196-239. Moskva.

Accepted, May 25, 1972.

Department of Animal Anatomy,

College of Agriculture,

Wrocław 12, Kożuchowska 1.

Anna AREAMOWSKA-PALIDER i Jacek ZABEOCKI

\section{MIËSIEN BARKOWO-POPRZECZNY W SWIETLE} ANATOMII POROWNAWCZEJ

\section{Streszczenie}

Na podstawie badań przeprowadzonych na gryzoniach, zajęczakach, mięsożernych i naczelnych autorzy dochodzą do wniosku, iż typowy $m$. omotransversarius występuje powszechnie u gryzoni i mięsożernych. U niektórych przedstawicieli obu tych grup ssaków pojawia się jeszcze dodatkowe pasmo mięśniowe (nie wyróżniane w NAV) określone przez nas jako $m$. omotransversarius dorsalis. Mięsień ten biegnąc od kręgu szczytowego do szyjnego kąta łopatki zlewa się w swym końcowym odcinku z m. rhomboideus. W antropotomii nie wyróżnia się mięśnia o nazwie omotransversarius. U naczelny homologiem tego mięśnia jest $m$. atlanto-scapularis ventralis, występujący $\mathrm{u}$ małp niższych i biegnący od kręgu szczytowego do wyrostka barkowego łopatki, a u form wyższych - do obojczyka. U małp obecny jest również $m$. omotransversarius dorsalis, czyli atlanto-scapularis dorsalis, który łącząc się z m. levator scapulae przekształca się tym samym w jego 
pierwszy, najsilniejszy ząb. U królika homologiem $m$. omotransversarius są dwa mięśnie tzw. $m$. basiohumeralis i $m$. levator scapulae maior. Przeprowadzone badania skłaniają autorów do wyrażenia poglądu iż $m$. omotransversarius nawiązuje łączność genetyczną nie $\mathrm{z} m$. trapezius, czy sterno-cleido-mastoideus, lecz $\mathrm{z} m$. rhomboideus. Unerwienie obu mięśni barkowo-poprzecznych głównie odgałęzieniami nerwów szyjnych a nie nerwem dodatkowym zdaje się potwierdzać słuszność wyrażonego wyżej poglądu. 